\title{
RETROSPECTIVE STUDY OF MYIASIS IN RUMINANTS AT BABUGANJ UPAZILLA VETERINARY HOSPITAL OF BARISAL
}

\author{
Most. Tahmina Khan ${ }^{1}$, Md. Tahmid Rahman Pavel ${ }^{1}$, Imam Hasan ${ }^{2}$, Md. Monowarul \\ Islam ${ }^{1}$, Md. Muket Mahmud', Saifa Nasar Trisha ${ }^{3}$, and Milton Talukder ${ }^{4 *}$ \\ 1Department of Microbiology and Hygiene; 'Department of Anatomy and Histology, and \\ ${ }^{3}$ Department of Pharmacology, Faculty of Veterinary Science, Bangladesh Agricultural University, \\ Mymensingh-2202, Bangladesh; ${ }^{4}$ Department of Physiology and Pharmacology, Patuakhali \\ Science and Technology University, Babuganj, Barisal, Bangladesh.
}

*Corresponding author: Milton Talukder; E-mail: talukder81@gmail.com

\begin{tabular}{|c|c|}
\hline ARTICLE INFC & ABSTRACT \\
\hline $\begin{array}{l}\text { Accepted } \\
12 \text { April, } 2018 \\
\text { Online } \\
30 \text { April, } 2018 \\
\text { Key words } \\
\text { Myiasis } \\
\text { Ruminants } \\
\text { Barisal }\end{array}$ & $\begin{array}{l}\text { The study was conducted to know the occurrence of myiasis in cattle and goats at } \\
\text { Babuganj Upazilla Veterinary Hospital, Barisal, Bangladesh. A total of } 160 \text { animals } \\
\text { were examined. Among them } 46 \text { animals were found to be myiasis infested. A } \\
\text { structured questionnaire was used to collect data on species, breed, age, sex, body } \\
\text { condition of the animal, onset and duration of illness, affected sites of myiasis. The } \\
\text { study was conducted during March } 2014 \text { to May } 2015 \text {. All the data that were collected } \\
\text { were entered into MS excel. Descriptive analysis was done by column and pie charts. It } \\
\text { was possible to follow the response of treatment using two treatment protocols. The } \\
\text { overall occurrence of myiasis was } 28.75 \% \text { where } 39.13 \% \text { in cattle and } 60.87 \% \text { in goat. } \\
\text { The occurrence was higher in cross breed cattle ( } 55.56 \%) \text { than the local ( } 44.44 \%) \text {. } \\
\text { Similarly the occurrence rate was higher in cross breed goat ( } 42.86 \%) \text { than local breed } \\
\text { (28.57\%). Less than } 6 \text { months aged animals ( } 71.73 \%) \text { and females (cattle-61.11\% and } \\
\text { goat- } 64.29 \%) \text { were more prone to myiasis. The frequency of maggot infestation was } \\
\text { higher in navel region ( } 54.35 \%) \text { followed by vaginal ( } 28.26 \% \text { ) and rectal ( } 10.87 \%) \\
\text { regions respectively. The percentage of recovery to Inj. SP vet, Inj. Asta vet and Inj. } \\
\text { Vermic were } 67.86 \% \text { Myiasis is the major problem in livestock production in our } \\
\text { country. Animals at high risk should be managed properly to avoid wound and special } \\
\text { attention on wound management should be given after castration and parturition to } \\
\text { prevent myiasis. }\end{array}$ \\
\hline
\end{tabular}

To cite this article: Khan MT, Md. TR Pavel, I Hasan, MM Islam, SN Trisha, Md. M Mahmud and M Talukder, 2018. Retrospective study of myiasis in ruminants at Babuganj Upazilla Veterinary Hospital of Barisal district. Res. Agric. Livest. Fish. 5 (1): 57-64.

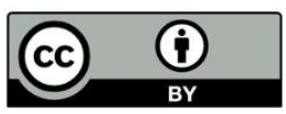

This is an open access article licensed under the terms of the Creative Commons Attribution 4.0 International License

www.agroaid-bd.org/ralf, E-mail: editor.ralf@gmail.com 


\section{INTRODUCTION}

The Greek word 'Myia' means fly and myiasis means a condition caused by the infestation or invasion of organs or tissues of living animals or mans by the larval stages of dipteran flies. They feed hosts dead or living tissues, liquid body substances or ingested food (Zumpt, 1965). Livestock plays an important role in poverty alleviation and economic development of Bangladesh. Scientific breeding, feeding, management and disease control are the key points of success in livetock improvement program. But one of the major constraints in the development of livestock is some diseases which occur due to poor management. Myiasis is the one of the disease condition which affects the animals in all ages. Myiasis causing flies are two types:1) primary myiasis causing flies whose larvae feed on living tissues; 2) secondary myiasis causing flies whose larvae feed on necrotic tissues and exudates.

Myiasis is distributed worldwide with seasonal variation, the occurrence of which is related to the latitude. Its incidence is higher in tropical latitude, south-east Asia and subtropics of Africa, where warm and humid climate prevail almost throughout the year, but uncommon in United States (Bolognia et al., 2008). Presence of wounds, soreness and laceration, wounds after delivery, castration, amputation of tail, FMD, foot rot, horn fracture, moist navel and vulva, wetted condition with urine contamination, sanitation and hygienic condition, wetted fleece, hair, recent surgery, bacterial skin contamination with foul odor, lack of aseptic wound care and fecal contamination etc. are still documented as the main predisposing factors for myiasis (Myiasis Wiki vet, 2011). As clinical point of view, myiasis can present as cutaneous myiasis, anal myiasis, genitor-urinary myiasis, nasopharyngeal myiasis, ocular myiasis, body cavity myiasis, wound myiasis, aural myiasis and intestinal myiasis (Sesterhenn et al., 2009). Maggot infestation in wound or ulcer is called traumatic myiasis or maggot wound. It may be primary or secondary depending on the species causing it (Venugopalan, 2004). The most frequent host for myiasis is cattle and goat $(46.4 \%)$, followed by dogs (15.3\%), humans $(14.7 \%)$, pigs $(6 \%)$, horses $(4 \%)$ and sheep (1\%) (Sergio et al., 2007). The available literature of different regions of the world contains a full description of myiatic wound, responsible flies with their life-cycle, pathogenesis, and clinical history with diagnosis and therapeutic regimen which was undertaken against the condition. In Bangladesh, very limited research was found with a view to explore occurrence and associated risk factors of myiasis in Bangladesh. The study was, therefore, undertaken to observe the occurrence of myiasis in cattle and goat in relation to species, age, sex, site of wound at Upazilla Veterinary Hospital, Babugonj, Barisal, Bangladesh.

\section{MATERIALS AND METHODS}

\section{Study Area and Population}

This study was conducted on myiasis in cattle and goat which were brought to Babuganj Upazilla Veterinary Hospital during March 2014 to May 2015. The species of animals examined mostly were local and cross with different exotic breed (e.g. Friesian). A total of 160 animals were examined.

\section{Questionnaire design and Data collection}

A structured questionnaire was used to collect animal level data like species, breed, age and sex, body condition of the animal, onset and duration of illness, affected sites of myiasis.

\section{Different treatment protocol used in the treatment of myiasis in goat}

Myiasis infested animals were treated by the drugs of penicillin and streptomycin combination, antihistaminic and ivermectin groups. Table 1 shows two treatment groups with different drugs, their dose and route of administration.

\section{Data analysis}

All data were entered into MS excel (Microsoft office excel-2007, USA). Descriptive statistical analysis was performed by column and pie chart and presented as percentage. 
Table 1. Different drugs used for treatment

\begin{tabular}{|l|l|l|}
\hline Groups & Name of drugs & Dose and Route of administration \\
\hline A (19 goats) & Inj. SP vet, Inj. Astavet, Inj. Vermic & $\begin{array}{l}\text { Inj. SP vet- } 1 \mathrm{ml} / 10 \mathrm{~kg}, \mathrm{IM} . \\
\text { Inj. Asta vet- } 0.5-1 \mathrm{ml} / 10 \mathrm{~kg}, \text { IM. } \\
\text { Inj. Ivermec-1ml/50kg,S/C. }\end{array}$ \\
\hline B (9 goats) & Inj. SP vet, Inj. Astavet vet & $\begin{array}{l}\text { Inj.SP vet- } 1 \mathrm{ml} / 10 \mathrm{~kg}, \mathrm{IM} . \\
\text { Inj.Asta vet- } 0.5-1 \mathrm{ml} / 10 \mathrm{~kg}, \text { IM. }\end{array}$ \\
\hline
\end{tabular}

\section{RESULTS AND DISCUSSION}

The distributions of myiasis were $56.52 \%, 26.09 \%, 13.04 \%$ and $4.35 \%$ respectively in Rahamatpur, Dehergati, Chadpasha, Madhabpasha (Figure 1). In this study, 46 myiasis cases were observed on which $60.87 \%$ were in goat, $39.13 \%$ in cattle (Figure 2) whereas (Sergio et al., 2007) recorded the most infested host for myiasis were cattle and goat $(46.4 \%)$ followed by dogs $(15.3 \%)$, humans $(14.7 \%)$, pigs $(6 \%)$, horses $(4 \%)$ and sheep (1\%). The overall proportional prevalence of myiasis was $28.75 \%$ (Figure 3 ) which is comparable to the result of (Giangaspero et al., 2011). Alahmed (2004) reported 3\% of 3129 cases in Italy, $2 \%$ of 3712 cases in Riyadh Region which were lower than our findings. However, some authors found higher prevalence than the present study that are $14.71 \%$ among 1964 cases in South-eastern part of Iran, $13.1 \%$ out of 1998 in South Iran, 59.9\% out of 554 in Ethiopia, $40.3 \%$ out of 387 in north-eastern part of Turkey, $31.9 \%$ out of 1276 cases in Turkey, $24 \%$ out of 520 in northern Jordan and $35.68 \%$ among 1303 cases in France, northern Mediterranean region respectively (Radfar and Hajmohammadi 2012; Shoorijeh et al., 2011; Gebremedhin, 2011; Arslan et al., 2008; Kara et al., 2005; Abo-Shehada et al., 2003; Dorchies et al., 2000). The apparent variation might be reflected the differences in the levels of management, housing, sanitation, sample sizes, duration of study, study setting (Hospital VS field) used among the researchers as well as genetic variation in disease resistance among the breeds. It was evident that cross breed goat were frequently infested with myiasis (42.86\%) than the local (28.57\%), JP (17.86\%) and Black Bengal (10.71\%) (Figure 4) which is higher than the findings were reported by Farkas et al., (1997) in sheep breed saying that incidence varied significantly in imported breeds $(28.8 \%)$ than in indigenous breeds $(5.8 \%)$. On the other hand, the prevalence of myiasis is higher in cross breed (55.56\%) than the local breed (44.44\%) among the 14 cattle investigated (Figure 5). (Kara et al., 2005) also reported lower infestation of fly larvae in native cattle. Figure 6 showed that less than 6 months old goats were more susceptible to myiasis $(71.73 \%)$. This finding is quite opposite to (Rahman et al., 2009) who reported predominantly higher wound myiasis in cattle over 2 years. (Kara et al., 2005) described that the intensity of the infestation decreased with the age of cattle.

However, (Arslan et al., 2008) reported that the infestation gradually increase with the age of cattle like: $30.0 \%$, for up to 1 -years-old, $40.0 \%$ for 1 to 3 years-old and $52.4 \%$ for more than 3 years old. While Al Ahmed (2004) stated prevalence of larval myiasis among young sheep was $60 \%$ and $40 \%$ among adults and (AboShehada et al., 2003) reported all age groups were infested in each month of the year. In this study, female animals were more frequently affected $(63 \%)$ with myiasis than the male $(37 \%)$ as shown in Figure 7 . Similar finding was also reported by Radfar and Hajmohammadi (2012). Some authors reported more cases in male than female (Orfanou et al., 2011; El-Rahman, 2010; Kara et al., 2005; Farkas et al., 1997). (Shoorijeh et al., 2011) and (Abo-Shehada et al., 2003) reported same level of infection in both sexes. The study revelaed that frequency of maggot infestation was higher in navel (54.35\%) and vaginal region (28.26\%) (Figure 8). Tyner, 2010 reported that the most common sites of myiasis of fawn were rump/hip, rectal/vaginal, tail, inter-digital space \& tarsal glands, metatarsal gland, teats, umbilicus, chest/back and pre-orbital gland. Radfar and Hajmohammadi (2012) reported $71.25 \%$ and $28.75 \%$ myiasis in subcutaneous tissue of back and flanks respectively in goat. Kumar and Ruprah (1984) described $27 \%$ myiasi in the navel area of newborn calves and $20 \%$ in vulvar region of recently calved cows. It is also observed that, myiasis was appreciably linked with alteration of demeanour of animals. The infected animals under the investigation were found dull or depressed (Figure 9). Two treatment protocols were used in myiasis and the recovery percentage was around $68 \%$ in case of combined use of Inj. SP Vet, Inj. Asta Vet and Inj. Vermic were $67.86 \%$. 


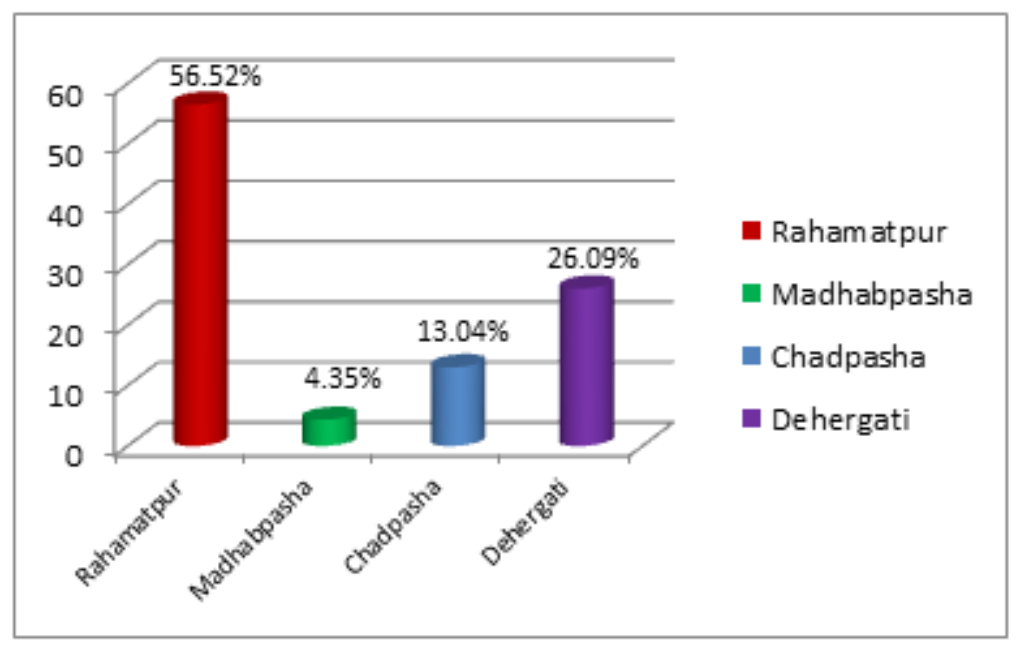

Figure 1. Area-wise distribution of myiasis studied at Babuganj Veterinary Hospital during March 2014 to May 2015.
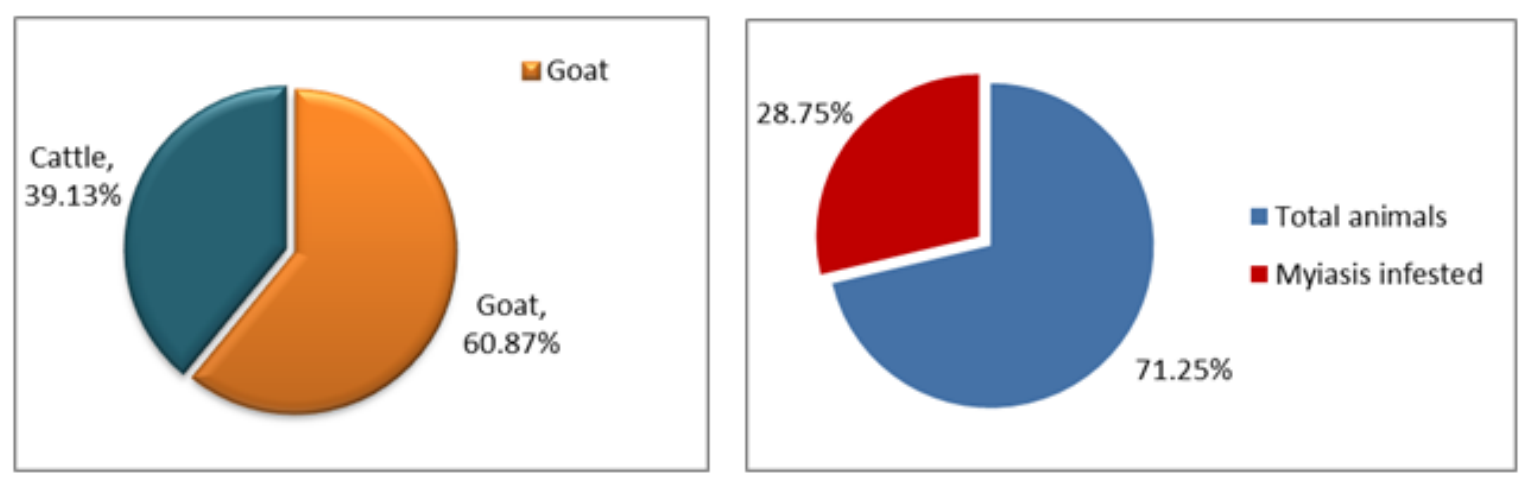

Figure 2. Species wise distribution of myiasis Figure 3. Overall occurrence of myiasis in Babuganj Veterinary Hospital during March 2014 to May 2015. 


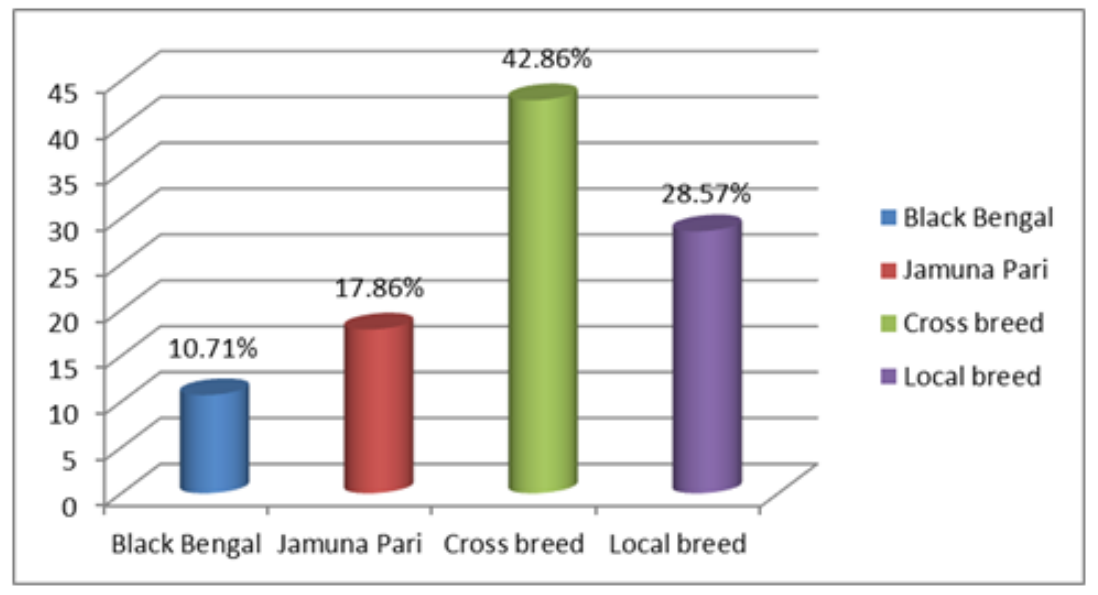

Figure 4. Breed wise distribution of myiasis in goats

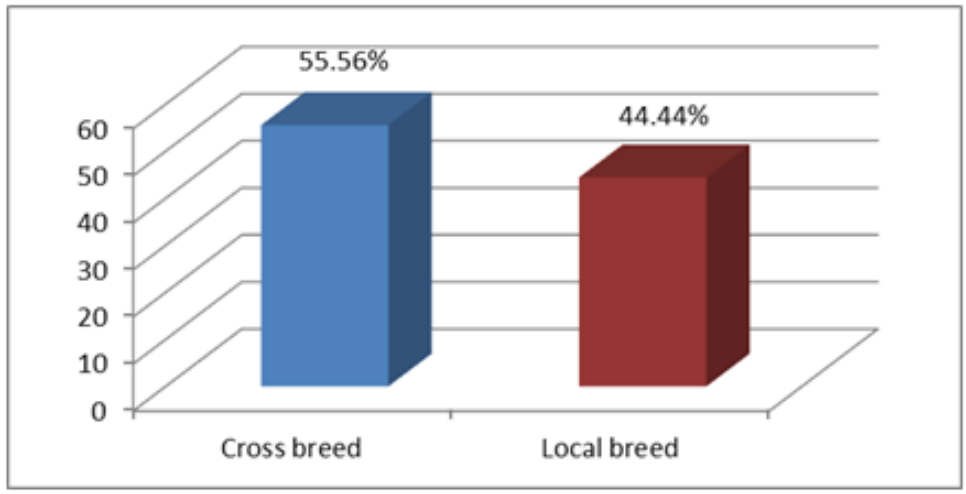

Figure 5. Breed wise distribution of myiasis in c attle 


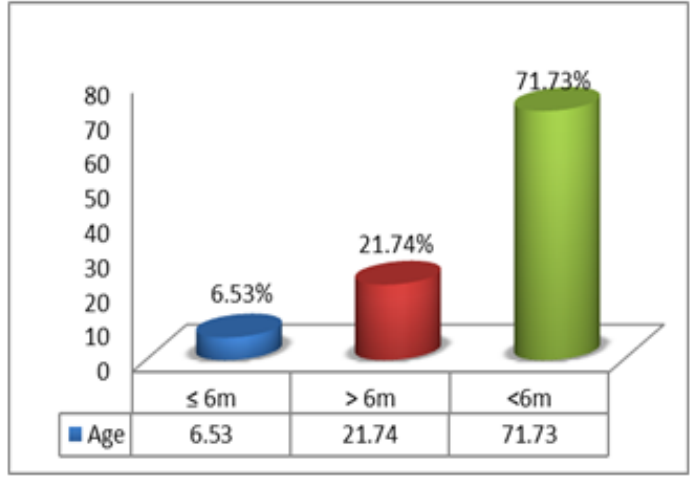

Figure 6. Age-wise distribution of myiasis in goat

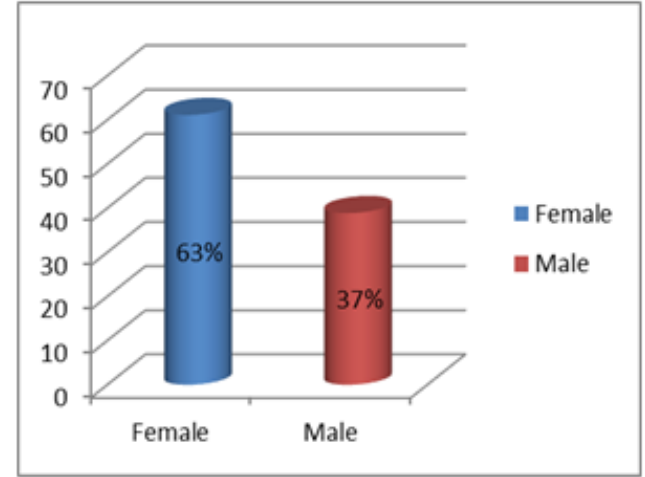

Figure 7. Sex wise distribution of myiasis in goat

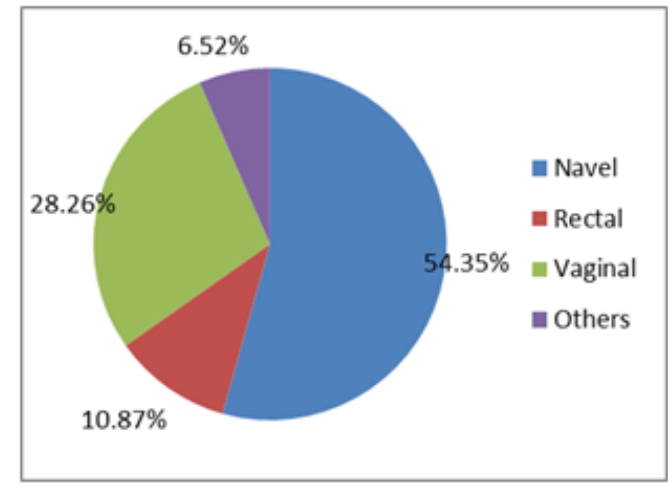

Figure 8. Common sites of myias is in different cattle and goats

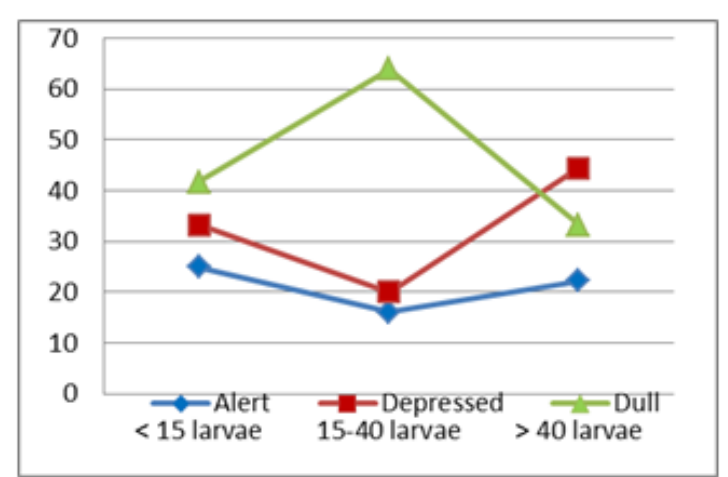

Figure 9. Distribution of myiasis ac cording to the demeanour of animals

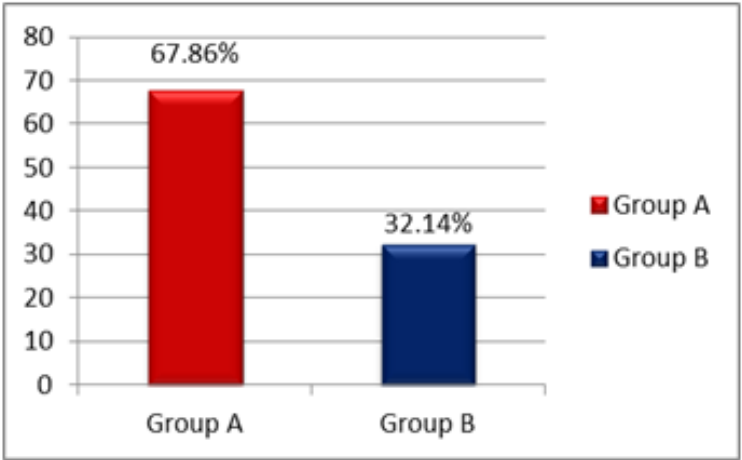

Figure 10. Recovery percentage of two treatment protocol 


\section{CONCLUSION}

Myiasis is very common and widely distributed disease at Babuganj Upazilla. Animals at high risk should be managed properly to avoid wound and special attention on wound management should be given after surgery (castration, amputation of tail, hernia, etc.) and parturition to prevent myiasis.

\section{ACKNOWLEDGEMENT}

The authors are grateful to the respected officers and members of veterinary hospitals authority and especially for the animal owners for their cordial participation to fill up the questionnaire.

\section{CONFLICT OF INTEREST}

The authors declare that they have no conflict of interest.

\section{REFERENCES}

1. Zumpt F, 1965. Myiasis in Man and Animalsin the Old World. A textbook for Physicians, Veterinarians and Zoologists. Butterworth Co, London.

2. Bolognia JL, JL Jorizzo, R Rapini. 2008. Cutaneous myiasis. Journal of Dermatology, Vol 1. $2^{\text {nd }}$ ed. Mosby Elsevier: 1300-01.

3. Myiasis Wiki-vet 2011. Myiasis-causing flies, The Animal Health \& Production Compendium (AHPC), published online by CABI during the OVAL Project.

4. Sesterhenn AM, W. Pfützner, DM Braulke, S Wiegand, JA Werner, 2009. Cutaneous manifestation of myiasis in malignant wounds of the head and neck.Europian Journal of Dermatology, 19: 64-68.

5. Venugopalan A, 2004. Wounds; Maggot wounds. Essential of Veterinary Surgery, $8^{\text {th }}$ Edition: $46,47$.

6. Sergio EB, DE José, BC Angel, C Franklin, S Janina, B Sabina and M Enrique, 2007. Incidence of myiasis in Panama during the eradication of Cochliomyiahominivorax.Sección de EntomologíaMédica, InstitutoConmemorativo Gorgas de Estudios de la Salud, PO Box 0816-02593, Panamá.

7. Giangaspero A, D Traversa, R Trentini, A Scala, D Otranto, 2011. Traumatic myiasis by Wohlfahrtiamagnifica in Italy. Journal of Veterinary Parasitology, 175(1-2):109-12.

8. Alahmed AM 2004. Myiasis in sheep farms in Riyadh Region, Saudi Arabia. Journal of Egyptian Society of Parasitology, 34(1):153-60.

9. Radfar $\mathrm{MH}$. and V Hajmohammadi, 2012.Prevalence of goat warble fly, Przhevalskiana silenusin southeastern of Iran; Science Parasitology, 13(2): 73-76.

10. Shoorijeh JS, A Tamadon, Sh Negahban, MA Behjadi, 2011; Prevalence of Oestrusovisin goats of Shiraz, southern Iran. Journal of Egyptian Society of Parasitology, 81: 43-49.

11. Gebremedhin EZ (2011). Prevalence of ovine and caprineoestrosis in Ambo, Ethiopian. Tropical Animal Health Production, 43(1): 265-70.

12. Arslan MO, M Kara and YY Gicik 2008. Epidemiology of Oestrusovis infestations in sheep in Kars province of north-eastern Turkey. Tropical Animal Health and Production, Volume 41: 299-305.

13. Kara M, M Arslan and Gicik Y. 2005. The Prevalence of Bovine Hypodermosis in Kars Province, Turkey. Tropical Animal Health and Production, Volume 37: 617-622.

14. Abo-Shehada MN, T Batainah, N Abuharfeil, PR Torgerson 2003. Oestrusovis larval myiasis among goats in northern Jordan; Preventive Veterinary Medicine, 59(1-2):13-9.

15. Dorchies $P$, JP Bergeaud, G Tabouret, $C$ Duranton, F Prevot, $P$ Jacquiet 2000.Prevalence and larval burden of oestrusovis (Linné 1761) in sheep and goats in northern mediterranean region of France.Veterinary Parasitology, 88(3-4): 269-73.

16. Farkas R., MJR Hall and F Kelemen, 1997. Wound myiasis of sheep in Hungary. Veterinary Parasitology, Volume 69, Issues 1-2: 133-144. 
17. Rahman MA, MA Hossain and MR Alam, 2009.Clinical evaluation of different treatment regimes for management of myiasis in cattle. Bang. Journal of veterinary medicine, $7(2): 348-352$.

18. Alahmed AM 2004. Myiasis in sheep farms in Riyadh Region, Saudi Arabia. Journal of Egyptian Society of Parasitology, 34(1):153-60.

19. Orfanou DC, E Papadopoulos, PJ Cripps, LV Athanasiou and GC Fthenakis 2011. Myiasis in a dog shelter in Greece: epidemiological and clinical features and therapeutic considerations. Veterinary Parasitology, 181(2-4): 374-8.

20. Sahar S. Abd El-Rahman 2010, Prevalence and Pathology of Nasal Myiasis in Camels Slaughtered in El-Zawia Province-Western Libya: with a Reference to Thyroid Alteration and Renal Lipidosis. Journal of Global Veterinarian, 4 (2): 190-197.

21. Beth Knapp-Tyner 2010. Deer Fawn Myiasis; Wild at Heart Wildlife Re-habilitation.

22. Kumar R and NS Ruprah, 1984.Incidence and etiology of cutaneous myiasis in domestic animals at Hissar [India].Indian Veterinary Journal, 61: 918-921. 